\title{
A RARE CASE OF SCAR ENDOMETRIOSIS FOLLOWING EPISIOTOMY
}

Rajlaxmi Jaysing Pardeshi' ${ }^{1}$, Anita More ${ }^{2}$, Mita Sase ${ }^{3}$, P. P. Panigrahi ${ }^{4}$, Aditya Pratap Singh ${ }^{5}$

\section{HOW TO CITE THIS ARTICLE:}

Rajlaxmi Jaysing Pardeshi, Anita More, Mita Sase, P. P. Panigrahi, Aditya Pratap Singh. "A Rare Case of Scar Endometriosis following Episiotomy". Journal of Evolution of Medical and Dental Sciences 2014; Vol. 3, Issue 53, October 16; Page: 12386-12389, DOI: 10.14260/jemds/2014/3639

ABSTRACT: Endometriosis is defined as ectopic presence of endometrial glands and stroma. It mainly affects pelvic peritoneal surfaces, ovaries and uterine ligaments. Even it can rarely affect vulva, vagina or perineum secondary to obstetric and surgical trauma. We are presenting a case of scar endometriosis following episiotomy in a woman with a positive history and classical physical findings who underwent wide surgical excision. The recovery was good with excellent functional results. The optimal management is wide surgical excision with additional tissue pathology to reduce recurrence and rule out malignancy.

KEYWORDS: Cesarean section, Episiotomy, Endometriosis, Scar.

INTRODCTION: Endometriosis is defined as extrauterine presence of functioning endometrial glands and stroma. It causes sterility and bothersome pain when localized intraperitoneally and extraperitoneally respectively.

In 1903 Robert Mayer through Bytom study first described endometriosis in postoperative scar. ${ }^{1}$ Various theories have been involved in the etiopathogenesis like retrograde menstruation, immunologic, inflammatory, hormonal, coelomic, lymphatic and genetic. The extra peritoneal sites are mainly abdominal scar but also are seen in rarely in episiotomy scar, bowel, bladder, lungs, kidneys, brain, umbilicus and groin. ${ }^{2}$ Cutaneous endometriosis in operative scars is rare. ${ }^{2,3}$

Clinical diagnosis is often confusing so it should be differentiated from hematoma, abscess, suture granuloma, desmoid tumour, soft tissue sarcoma and metastatic cancer. ${ }^{2}$ It is usually diagnosed by clinical symptom of a slow growing lump in the scar or nearby area which is painful during menstruation. Sometimes it is associated with cyclicbleeding. ${ }^{2}$ We present a rare case of endometriosis at the episiotomy scar who had complaints of cyclical pain.

CASE HISTORY: A 25 year old primipara presented to us with pain and swelling in the perineal region. She had progressive and cyclical pain coinciding with her menstruation. She had taken several antibiotic courses but had no relief. Pain was severe that it was preventing her from sitting, coitus and performing day-to-day activities. She had a history of vaginal delivery 2 years back with a left mediolateral episiotomy scar. She had complaints of pain in episiotomy site after six month and noticed swelling over perineum after $1 \frac{1 / 2}{2}$ of her delivery.

On examination there was a firm palpable nodule measuring $4 \times 2 \mathrm{~cm}$ size at her episiotomy site. Internal examination was normal. She was planned for excisional biopsy for confirmation of diagnosis.

Wide excision was performed under spinal anesthesia. Grossly the swelling had small cysts and few areas with dark chocolate brown colored material. The boundary was not clear. The histopathological examination had ectopic endometrial glands with surrounding cellular stroma and 
squamous epithelium of vaginal wall. Post-operative period was uneventful. The patient was discharged on $7^{\text {th }}$ day and followed up after 3 months with symptom free period.

DISCUSSION: The incidence of episiotomy scar endometrioma is less as compared to cesarean section scar.2, 3 The etiopathogenesis of localization in surgical scar is related to the iatrogenic implantation during delivery or surgery. It is a steroid dependent condition with a peculiar genetic background. ${ }^{4}$ Hormonal and immunologic factors play role in its pathogenesis. Transport theory suggests endometrial cells transport to distant location during surgery or any other procedure.0.74\% cases of perineal endometriosis were seen in episiotomy scar. ${ }^{4}$

The extraperitoneal sites are rarely involved. ${ }^{5}$ It confirms that extra pelvic form is due to complication of surgery. ${ }^{6}$ The incidence of scar endometriosis is $0.2 \%$ with CS as compared to $0.06 \%$ with vaginal delivery is reported in a large study series. ${ }^{7}$ Cyclical symptoms of pain and bleeding at scar site is practically pathognomic in a woman with a prior history of surgery on the uterus. ${ }^{8}$ Bothersome pain is due to involvement of sensory nerve fibers in deep infiltrating lesions. With classical history and physical examination, no other diagnostic tools are required. However confirmation with USG+Doppler, CT, MRI and Epiluminescence microscopy for superficial lesions to exclude melanoma can be done. FNAC though easy and good but carries the risk of dissemination.

Wide local excision is considered as the gold standard for both diagnosis and treatment. ${ }^{8}$ The resection must be complete with clear margins to prevent recurrence and the potential risk of malignant transformation. ${ }^{8}$ There were 8 from 33(24\%) recurrence in 19 months after excision. ${ }^{1}$ In wide excision a narrow incision has high recurrence rate.

CONCLUSION: Scar endometriosis though rare, any woman with a positive history and classical findings must be treated in time if interfering her routine. A general physician approach may delay the appropriate diagnosis. With no burden of expensive diagnostic tools but few, recently introduced, less invasive tests at molecular level can thus help a woman cure of her disease at earliest.

\section{REFERENCES:}

1. Olejek A, Zamłyński J, Podwińska E, Horák S, Paliga-Żytniewska M, Kellas-lęczka S. Guzy endometrialne $\mathrm{w}$ bliznach po cięciu cesarskim. [Abdominal Wall endometrioma in the cesarean section scar]. Ginekol Pol 2008, 79, 612-5.

2. Horton JD, De Zee KJ, Ahnfeldt EP, Wagner M. Abdominal wall endometriosis: a surgeon's perspective and review of 445 cases. Am J Surg 2008, 196, 207-12.

3. Lattuada D, Somigliana E, Viganò P, Candiani M, Pardi G, Di Blasio AM. Genetics of endometriosis: a role for the progesterone receptor gene polymorphism PROGINS? Clinical Endocrinology 2004, 61, 190-4.

4. Leite GKC, de Carvalho LFP, Koreks H, Guazzelli TF, Kenj G, de Toledo V. Scar endometrioma following obstetric surgical incisions: retrospective study on 33 cases and revieJw of the literature. Sao Paulo Med J 2009, 127, 270-7.

5. Zhu Z, Al-Beiti MAM, Tang L, Liu X, Lu X. Clinical characteristic analysis of 32 patients with abdominal incision endometriosis. J Obstet Gynaecol 2008, 28, 742-5.

6. Francica J, Giardiello C, Angelone G et al. Abdominal wall endometrioma near cesarean delivery scars. J Ultrasound Med 2003. 22: 1041-1047. 


\section{CASE REPORT}

7. Nominato NS, Prates LFVS, Lauar I, Morais J, Maia L, Geber S. Caesarean section greatly increases risk of scar endometriosis. Eur J Obstet Gynecol Reprod Biol 2010, 152, 83-5.

8. Sengul I, Sengul D, Kahyaoglu S. Incisional endometriosis: a report of 3 cases. Can J Surg 2009, 52(5): 444-445.

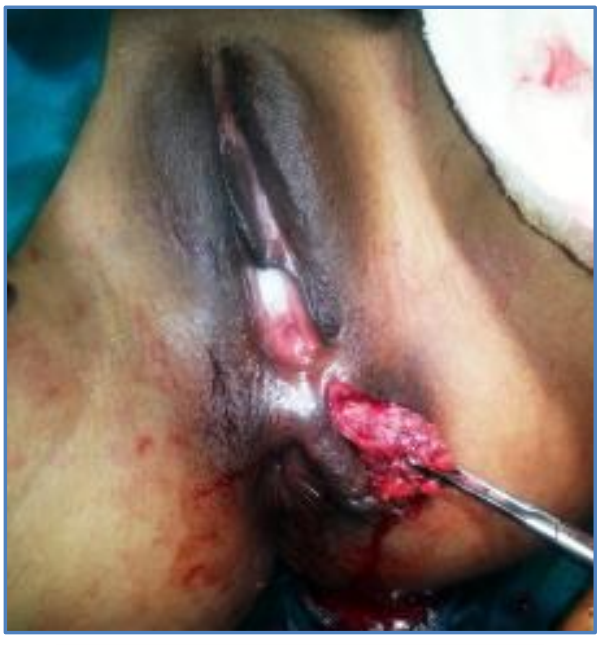

Fig. 1: Intra operative photograph showing

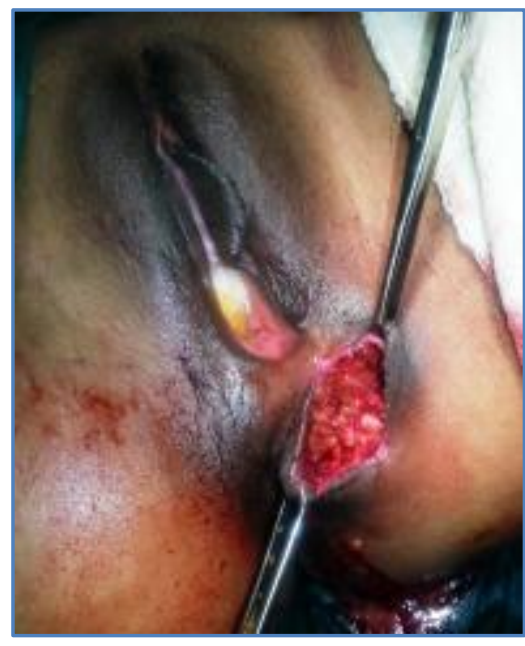

Fig. 2: Intra operative photo showing after excision of scar endometriosis.

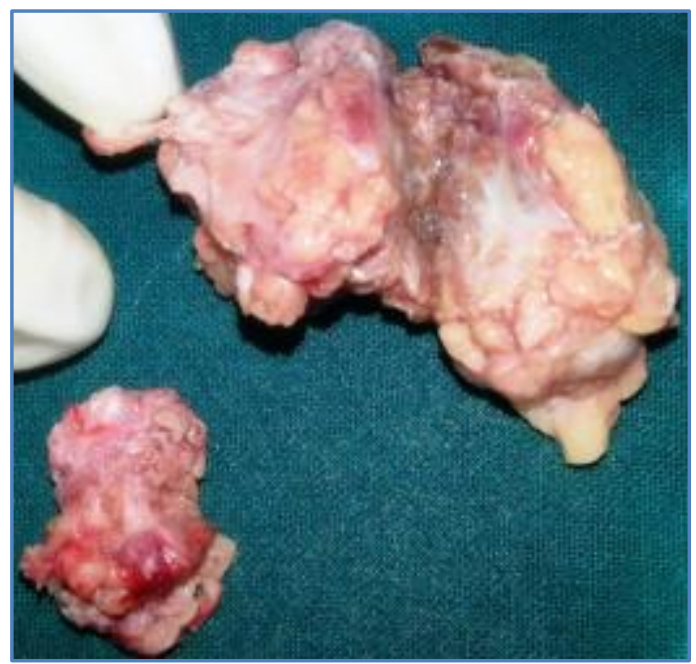

Fig. 3: Photo showing scar endometriosis specimen 


\section{CASE REPORT}

\section{AUTHORS:}

1. Rajlaxmi Jaysing Pardeshi

2. Anita More

3. Mita Sase

4. P. P. Panigrahi

5. Aditya Pratap Singh.

\section{PARTICULARS OF CONTRIBUTORS:}

1. MBBS, M.S., Department of Obstetrics and Gynaecology, MIMER Medical College, Talegaon, Pune.

2. M.B.B.S., DGO, DNB, Associate Professor, Department of Obstetrics and Gynaecology, MIMER Medical College, Talegaon, Pune.

3. M.B.B.S., M.S., Assistant Professor, Department of Obstetrics and Gynaecology, MIMER Medical College, Talegaon, Pune.

4. M.B.B.S., M.S., HOD, Department of Obstetrics and Gynaecology, MIMER Medical College, Talegaon, Pune.
5. M.B.B.S., M.S., M.ch., (Resident), Department of Pediatric Surgery, SMS Medical College, Jaipur.

\section{NAME ADDRESS EMAIL ID OF THE CORRESPONDING AUTHOR:}

Dr. Aditya Pratap Singh, Near The Mali Hostel,

Main Bali Road,

Falna District, Pali,

Rajasthan.

Email: dr.adisms@gmail.com

Date of Submission: 05/09/2014.

Date of Peer Review: 06/09/2014.

Date of Acceptance: 09/10/2014.

Date of Publishing: 16/10/2014. 